\title{
The Efficacy of Evolving Technology in Conceptualizing Pedagogy and Practice in Higher Education
}

\author{
Wahab Ali ${ }^{1}$ \\ ${ }^{1}$ Associate Professor, Education Department, School of Humanities \& Arts, University of Fiji, Lautoka, Fiji \\ Correspondence: Wahab Ali, Education Department, School of Humanities \& Arts, University of Fiji, Lautoka, \\ Fiji. Tel: 679-664-0600. E-mail: wahaba@unifiji.ac.fj
}

Received: February 9, 2019

Accepted: February 26, 2019 Online Published: March 11, 2019

doi:10.5539/hes.v9n2p81

URL: https://doi.org/10.5539/hes.v9n2p81

\begin{abstract}
The proliferation of new forms of information and communication technology (ICT) has inundated the learning patterns of students at all levels and particularly at higher education level. The efficacy of teaching the digital generation of learners without a firm grasp of how they learn is like embarking upon a perpetual journey. Invariably, today's students have been mesmerized by digital gadgets from a very small age and this experience calls for a technology integrated paradigm. Hence, the current study focuses on the influence of evolving technology in conceptualizing pedagogy and practice in higher education. It explores staff members' technological know-how and how they are able to influence learning at a University in Fiji. An exploratory research design was selected and a survey consisting of Likert scale items was administered. Subsequently, SPSS Statistical software was used for data analytical and reporting purpose. Findings are discussed in collaboration with a robust meta-analysis of literature and they reveal that apart from resources, staff readiness, confidence and motivation play important function in ICT integrated learning. This paper proposes that staff members should use technology and technological gadgets to enhance digital literacy and numeracy that in turn, would create a digitally vibrant society.
\end{abstract}

Keywords: technology, digital generation, ICT savvy, millennials, learning platforms, internet, pedagogy

\section{Introduction}

The rapid evolution of Information Communication and Technology (ICT) and the increasing complexity that comes with its exploding potential explains why integration of technology in education continues to receive special attention. The dawning of the new millennium witnessed the initial entry of the Net Generation into our higher education institutes, which required them to brace themselves for a new lineage of learners who had distinctive interests and dispositions. Many revised education standards emphasize that staff members must demonstrate the ability to develop learning environments and experiences that effectively integrate technology particularly at higher education (HE) level. More so, ICT is regarded as an influential agent for educational innovation and reform and there is a profusion of studies that have revealed that if it is properly implemented, it can enhance student performance and education quality (Elisha Ondieki, Odini, \& Ojiambo, 2013; Jaffer, Ngambi, \& Czerniewicz, 2007; Sadegül Akbaba, Kalayci, \& Avci, 2011; Shah \& Stanford; Zaffar Ahmed \& Shakeel Ahmed, 2011). In light of previous research, evidences support the view that as time goes by skills in using ICT will be an essential requirement for both staff and students (Coll, Mauri, \& Onrubia, 2009; Jung, 2005).

Subsequently, there is no doubt that the implementation of wireless and mobile technology in the classroom enables both students and teachers to have unfettered access to quality information irrespective of time and context (Agbatogun, 2013). However, it must be established that lecturers are the key players to see the effective integration of ICT in HE. Moreover, according to Cant and Bothma (2010) educators' perceptions needs to be considered in order to effectively integrate ICT within the four walls of a classroom. As such it is vital to appreciate and comprehend lecturers' knowledge and perceptions concerning different interactive digital technology (IDT) in order to facilitate its effective integration in the classroom. The IDT in education are effective means to widen educational prospects for learners as well as lecturers in higher education (HE). As such it is crucial to realize the importance of technology-enhanced learning and teaching for staff in HE. Subsequently, having a better understanding of staff members and their ICT knowledge and skills will enable a 
better integration of technology in the classrooms. These conspicuous perceptions provided the intrinsic motivation for this study.

\subsection{Aim of the Study}

There has been massive infiltration of technological advancement in all spheres of life and including HE institutes. These changes demand a paradigm shift in pedagogy and practice at HE where success depends on staff readiness and their skills in handling ICT integrated learning (Thurlings, Evers, \& Vermeulen, 2015). Subsequently, this study intends to examine the influence of evolving technology in conceptualizing pedagogy and practice in higher education.

\subsection{Research Questions}

This study was guided by the following overarching question:

What is the influence of evolving technology in conceptualizing pedagogy and practice in higher education?

The study was further inspired by the ensuing auxiliary questions:

- What technological tools and Apps do you use in your class in higher education?

- What is your perception of ICT integration in learning and teaching?

- How do your students perceive the integration of ICT in lessons?

- How can ICT integration be conceptualized as an effective pedagogical reform in HE?

\subsection{Significance of Study}

The findings of this study are considered to be of great importance to various stakeholders for several reasons. Foremost, there has been a paucity of previous research regarding lecturers' perceptions about the integration of ICT in their teaching and learning at HE level. This study will help uncover critical areas and contribute to local literature on the subject, which in turn could be used by relevant authorities in improving their education initiatives. Lecturers' may realize the importance of undertaking studies in information technology and online modes as a means of up-skilling their teaching abilities. The finding of this study will redound to the benefit of HE institutions by providing them important insights into ICT integrated teaching enabling them to strengthen their programs to better prepare lecturers' to deal with the diverse exigencies of the digital generation.

Findings will be of great importance to the administrators in establishing the importance of ICT integration and provision of appropriate infrastructural support. Administration needs to have suitable learning rooms and ICT labs for online teaching and learning. Findings will no doubt enable them to comprehend the importance of having pertinent ICT tools, Educational Apps and Learning Platforms like Moodle. This understanding will enable them to budget accordingly as certain Apps and online programs may be costly. One such expense would be the installation of WIFI and high quality internet system. However, much of the expenses may be one off as many of the ICT tools would be durable and used over the years. Having cutting edge technological tools and delivery system will entice prospective students thus boosting the student population and in return contributing positively towards the financial well-being of the institution.

Furthermore the study makes contribution through its findings by revealing the difference between various groups of staff and their attitudes towards the integration of ICT in teaching and learning. Notably, the findings will be of great value to the staff as they are in constant touch with the students and will be able to better understand their behaviour and address classroom management issues amicably. In a similar vein, it will also present important information to Education authorities about the benefits of ICT integrated learning enabling them to include them as pedagogical reforms in education. In particular, they may have to revisit their curriculum so that ICT knowledge is included in their text at primary and secondary levels. This adaptation would better prepare the students for ICT integrated pedagogy at HE institutions. Subsequently, the recommendations of the study, if implemented, will allow HE institutes to create an interactive and enjoyable learning environment for all students.

The subsequent section presents a corpus of robust literature on lecturers' perspectives in coalescence with the integration of ICT, which is characterized as being at the heart of the new digital orientation.

\section{Literature Review}

As $21^{\text {st }}$ century educators one must understand and appreciate that just like millennials, iGen also like to collaborate and do collaborative learning but there is a difference. For example, it is quite surprising to note that although they desire to stay connected with others, their favoured mode is through texting over face-to-face communication (Carr, 2017). As such, previous pedagogies so applicable and designed for earlier generations may be futile with the iGens if not properly administered. For instance, it has often been observed that students 
sitting around tables are busy on their smart phones without conversation or discussion. Accordingly, Carr (2017) asserts that mobile phones inhibit the growth of interactive and interpersonal touch and this detachment leads to gradual decline in empathy and understanding in the individuals. The iGens have a special yearning for ICT tools and internet assisted teaching and learning. As such, integrating ICT in pedagogy motivates students and enables them to be creative in their presentations with multi-media and virtual modes (Rosen, 2010). The use of ICT is becoming a mandatory task for lecturers' in HE institutes globally. Not only teaching staff have to use ICT during computer science classes, but they are also encouraged to use them as instruments to teach other subjects (Chisalita \& Cretu, 2015).

To effectively initiate and implement ICT in classes, a lot depends on the staff and students' attitudes (Buabeng-Andoh, 2015). It is important to understand Lecturers' perceptions about integrating technology because it is them who are the real drivers in making the difference in the classrooms. Evidence for in support of this position can be found in the work of Drossel, Eickelmann and Gerick (2017), who claim that positive attitude of staff on ICT integration for is vital successful implementation in educational institutions. As such it needs to be established that lecturers' disposition and perceptions of ICT use and importance impacts their decisions and actions they take in teaching. On similar note, Gilakjani, Leong, and Ismail (2013) affirm that lecturers' attitudes and perceptions of ICT influences either their willingness or reluctance towards using technology in their teaching. Lecturers' perceptions and believe systems are crucial to successful adoption of technology in teaching. As literature entails, lecturers' lack of knowledge, phobia of computers, resistance to change and lack of openness to innovation have been known as barriers to effective integration of ICT at all levels (Becker, 2000). Noting the convincing role lecturers play in the integration of ICT in learning validates the rationale for the administration of the current research.

Despite certain shortfalls, the integration of technology in learning and teaching has the potential to revolutionize an archaic education system (Aczel, Peake, \& Hardy, 2008). Similar sentiments have been expressed by Hew and Brush (2007) who claim that ICT has become an integral part of our lives as such its integration in the education arena has become inevitable and unavoidable. On similar note while addressing the implementation of technology in their study, Drossel et at., (2017) assert that a knowledge-based economy warrants technology-ready workers and this interest in turn places enormous pressure on educational institutions to implement ICT integrated learning environment. Notwithstanding the many benefits, Lim and Khine (2006), Zaffar and Shakeel (2011) and $\mathrm{Fu}$ (2013), firmly believe that limitations such as lack of infrastructure in institutions, ICT tools, electricity and support services are significant barriers to the effective integration of ICT in education. They are assertive that for successful implementation of ICT in higher education, a robust ICT infrastructure is of essence and an unavoidable prerequisite. The information and technology-based society demands incessant improvements to prepare new generations to take full advantage of the new socio-cultural and economic conditions. These types of exigencies require a new genus of lecturers' who are themselves well versed with ICT knowledge and skills (Twidle, Sorensen, Childs, Godwin, \& Dussart, 2006).

Accordingly, Barber and Mourshed (2007) ascertain that lecturers' play a key role in enhancing student performance and as such they need to be well versed with ICT knowledge. The views expressed by Barber and Mourshed (2007) gets support in the work of Kay (2006) who had earlier established and recommended that in order for lecturers' to be effective implementers of ICT, they need to learn it and its application during their teacher training programs or professional development sessions. However, Twidle et al., (2006) are quite skeptical about lecturers' integrating ICT in their teaching despite having training is because of the complexity of the issue. They believe that some lecturers' are not fully confident and knowledgeble to use technological tools effectively as pedagogical practices. Drawing on the results of previous research it can be established that just having the resources is not good enough as lecturers' need to be well trained to use technological tools and applications competently. Subsequently, lecturers' competence and and vision about ICT assimilation greatly impacts the success of it being implemented as effective pedagogical practices.Evidently, Vrasidas and McIsaac (2001) are assertive that apart from infrastructure and lack of resources, lecturers' lack of ICT related competencies has been one of the main impediments for its effective integration in teaching.

\section{Methodology}

Methodology demystifies the research process and the belief systems that are constructed on ontological, epistemological, and methodological assumptions. Subsequently, this study was conducted from within an interpretive paradigm, and this action has implications for the selection of an appropriate research design. Accordingly, an exploratory research design was found to be most appropriate to unveil the salient intricacies, particularly at the local level. In the present case, not much is known about lecturers' perception of ICT integration in teaching at higher education level. Exploratory studies are a valuable means of asking questions to 
establish baseline information (Yin, 2011). A likert type survey was developed and employed (GarcÃa, 2014) as it is a preferred instrument for those who are involved in active research (Wilkinson \& Birmingham, 2003). Further validations in the selection of survey research can be found in the words of Baker and Mukherjee (2007) who claim that survey research is the most appropriate method if researchers need information that is unavailable and want to make generalizations by studying a small portion of that population. Having considered previous procedures, a survey using Likert type scales was administered to establish staff members' understanding of the influence of evolving technology in conceptualizing pedagogy and practice in higher education.

Subsequently, a sample of staff members were randomly considered since it was not possible to survey all the staff members because of the number and their availability. Subsequently, 80 staff members were randomly selected and the survey was electronically mailed to them. Conventionally, 67 is a reasonable number relishing a confidence level of $95 \%$ with 0.5 as the margin of error. In regards to instrumentation, diverse variables were considered for the various items in the survey to assess the influence of evolving technology as perceived by staff members. The Cronbach's coefficient alpha $[\alpha]$ was used to assess the reliability of the study constructs. Eventually, the overall reliability of the constructs was .712 on 15 items that are discussed for the purpose of this study. Table 1 shows the Cronbach's Alpha values of the study constructs. The average value of Cronbach's Alpha reveals that the constructs are at an acceptable level to adequately address the research questions. Ethical issues were taken into consideration throughout the course of this study and all relevant information such as the aim and the purpose of the study were communicated well in advance to the participants.

Table 1. Reliability Statistics of Study Constructs

\begin{tabular}{ll}
\hline Cronbach's Alpha & $\mathrm{N}$ of Items \\
\hline .712 & 15 \\
\hline
\end{tabular}

In similar vein, credibility and trustworthiness were issues taken into consideration during the entire study as the data was analysed and discussed neutrally without any bias and preconception. The findings section will discuss the items in the table with reference to pertinent literature wherever possible.

\section{Findings and Discussion}

This section presents the findings based on the research questions according to thematic approach. As such, 15 items are discussed in relation to pertinent discourse. Table 2 depicts the item statistics for the study. 
Table 2. Item-Total statistics

\begin{tabular}{|c|c|c|c|c|}
\hline & $\begin{array}{l}\text { Scale Mean if } \\
\text { Item Deleted }\end{array}$ & $\begin{array}{l}\text { Scale Variance if } \\
\text { Item Deleted }\end{array}$ & $\begin{array}{l}\text { Corrected Item-Total } \\
\text { Correlation }\end{array}$ & $\begin{array}{l}\text { Cronbach's Alpha if } \\
\text { Item Deleted }\end{array}$ \\
\hline How long have you been teaching? & 60.87 & 22.542 & .286 & .709 \\
\hline $\begin{array}{l}\text { What learning Apps and Platforms do you } \\
\text { often use? }\end{array}$ & 60.42 & 21.489 & .486 & .673 \\
\hline $\begin{array}{l}\text { Integration of ICT makes lesson more } \\
\text { meaningful. }\end{array}$ & 60.34 & 25.562 & .189 & .710 \\
\hline $\begin{array}{l}\text { Online and Hybrid mode are the upcoming } \\
\text { pedagogies in the } 21 \text { st century. }\end{array}$ & 60.22 & 25.449 & .214 & .708 \\
\hline $\begin{array}{l}\text { Backup ICT support is necessary for effective } \\
\text { delivery of ICT integrated pedagogy. }\end{array}$ & 60.22 & 25.661 & .132 & .717 \\
\hline $\begin{array}{l}\text { Staff members need to build in confidence to } \\
\text { integrate ICT in teaching. }\end{array}$ & 60.27 & 24.715 & .310 & .699 \\
\hline $\begin{array}{l}\text { Students also need basic ICT knowledge in } \\
\text { order to apply them effectively. }\end{array}$ & 60.12 & 25.773 & .193 & .709 \\
\hline $\begin{array}{l}\text { High quality internet service facilitates } \\
\text { integration of ICT. }\end{array}$ & 60.51 & 24.345 & .283 & .702 \\
\hline $\begin{array}{l}\text { ICT integration is a common feature across } \\
\text { tertiary institution. }\end{array}$ & 60.15 & 24.432 & .287 & .701 \\
\hline $\begin{array}{l}\text { ICT should be an integral aspect of all } \\
\text { university qualifications. }\end{array}$ & 60.33 & 20.891 & .638 & .652 \\
\hline $\begin{array}{l}\text { Staff professional development in ICT will } \\
\text { improve integration. }\end{array}$ & 60.21 & 22.077 & .563 & .666 \\
\hline $\begin{array}{l}\text { ICT should be seen as a facilitator of } 21 \text { st } \\
\text { century pedagogy. }\end{array}$ & 60.21 & 23.137 & .405 & .687 \\
\hline $\begin{array}{l}\text { ICT integrated pedagogy requires adequate } \\
\text { preparation and planning. }\end{array}$ & 60.22 & 24.752 & .348 & .696 \\
\hline $\begin{array}{l}\text { ICT integration makes teaching and learning } \\
\text { engaging and interactive. }\end{array}$ & 60.04 & 26.013 & .139 & .714 \\
\hline ICT should be integrated in all programs. & 60.22 & 25.661 & 192 & .710 \\
\hline
\end{tabular}

The ensuing sections present the findings in collaboration with pertinent literature on the influence of technology in conceptualizing pedagogy and practice at HE level.

\section{Technological Tools for Integration}

Willingness to embrace change is a major requirement for successful integration of technology as it provides students opportunities to learn and apply the required 21 st century skills. The teaching staff in the current study consists of a wide range of academics but majority (76\%) of them are at lecturer and assistant lecturer level while the remaining are at senior positions. Findings reveal that majority of the staff members appreciate the importance of ICT integration in learning and teaching. While many $(26 \%)$ of the staff members use laptop, projector and speaker as major tools for integrating ICT in their classes, majority (51\%) use only laptop and projector. A few (7\%) of the staff members were found to be using tablets and smart phones effectively in their classes. Lecturers seem to be more familiar with PowerPoint and integrate educational videos to supplement their teaching and this assimilation in turn makes learning meaningful and enjoyable for the students.

Subsequently, Moodle (45\%) and YouTube (42\%) seem to be the most common learning platforms used by staff members (see Table 3). There is no doubt that the integration of the ICT as an instructional device in academic courses has escalated at a rapid rate. Subsequently universities and colleges have started implementing applications like Moodle and educational Blogs to supplement existing pedagogy and practice (Becker, 2000). Ruzgar (2005) agrees with (Becker, 2000) that it is common in universities and colleges to provide online resources to supplement traditional teaching methods. In a study undertaken by Laird and Kuh (2005) confirm that students' responses to the technology related items imply that majority of them use information technology regularly for private as well as educational purposes. An earlier study by the author reveals that majority (72\%) of the students make use of their mobile phones to access Moodle (Ali, 2018) which is an e-learning platform used by many educational institutions globally (Moodle org, 2017). 
Table 3. Learning Apps and Platforms often use by Staff

\begin{tabular}{lll}
\hline & Frequency & Percent \\
\hline Moodle & 30 & 44.8 \\
Youtube & 28 & 41.8 \\
Viber & 3 & 4.5 \\
Google Play & 3 & 4.5 \\
SlideShare & 3 & 4.5 \\
Total & 67 & 100.0 \\
\hline
\end{tabular}

There is no doubt that new technologies have great potential to make teaching and learning at HE institutions more interactive and meaningful. Adopting ICT integrated pedagogies enable universities to meet a broader range of learners' needs, enabling a mix of face-to-face and blended learning opportunities. Such conditions allow students to study at their own pace and they remove time and context barriers. This flexible learning approach commonly known as blended/hybrid is of great convenience to distant and part time students as it enables them complete their studies in their own space and time.

\section{ICT integrated Pedagogy}

The integration of technology as a pedagogical reform is considered to be a worthwhile and effective classroom strategy. Teaching staff in colleges and universities are supported and inspired to incorporate technology into their instructional practices, as it is posited that technology has the potency to unlock the future. The findings of the current research are in concurrence with the findings of Gupta and Dharamveer (2017) as all the lecturers' either agreed or strongly agreed that ICT helped them to improve teaching with more updated materials. Previous research reveals that educational stakeholders globally have a very high expectation of ICT integrated learning environment as they view it as a catalyst to achieving quality education (Jaffer et al., 2007). The rapid integration of technology in education domain has brought notable changes in the twenty-first century students, as well as it has positively affected modern industry demands (Buabeng-Andoh \& Totimeh, 2012). According to a UNESCO Report, technology is viewed as a very important tool for change and development because of its ability to influence the entire educational landscape. As such, there is a high demand on educational institutions the world over to integrate ICT in teaching to meet the needs of the students belonging to the digital generation (UNESCO, 2002).

Considering the many socio-economic benefits of having graduates having undergone ICT integrated learning environment, it has become necessary for HE institutes to take the lead and create appropriate learning environment. In the current study majority (93\%) of the staff members are in occurrence that ICT integration is a common feature across tertiary institutions. They further believe that this integration makes learning more interesting and enjoyable (see Table 4).

Table 4. ICT integration makes teaching and learning engaging and interactive

\begin{tabular}{lll}
\hline & Frequency & Percent \\
\hline Strongly Agree & 40 & 59.7 \\
Agree & 24 & 35.8 \\
Unsure & 3 & 4.5 \\
Total & 67 & 100.0 \\
\hline
\end{tabular}

Findings reveal that majority (95\%) of the staff ascertain that integrating ICT makes their lesson interesting and meaningful. The findings are supported by previous literature which claims that students find learning more interesting and engaging in ICT integrated environment (Cheta, 2014; Morrison, 2015). There is no doubt that technology presents a variety of learning tools and opportunities to make learning exciting and enjoyable. The various learning platforms and Applications enable students to learn the existing content in new and dynamic style. For example, learning platforms are social in nature and support customization of content based on learners' choice and interest (Corrin, Bennett, \& Lockyer, 2011). Subsequently, online and hybrid modes are viewed as the upcoming pedagogies in the in the 21 st century (see Table 5) 
Table 5. Online and Hybrid mode as upcoming pedagogies

\begin{tabular}{lll}
\hline & Frequency & Percent \\
\hline Strongly Agree & 30 & 44.8 \\
Agree & 32 & 47.8 \\
Unsure & 5 & 7.5 \\
Total & 67 & 100.0 \\
\hline
\end{tabular}

Findings reveal that majority (92\%) of the staff members view online and hybrid modes as imminent pedagogies in tertiary teaching. Hybrid method has been well accepted and implemented in colleges and universities globally and literature reveals a vast increase in its implementation globally. For instance, according to Allen and Seaman (2013) the number of HE institutions having online programs have increased from $48.9 \%$ in 2002 to $70.6 \%$ in 2012 (Allen \& Seaman, 2013). There is no doubt that rapid technological developments have changed the educational flora and fauna for many students. Carrying bags full of textbooks have become a thing of the past for many digital native tertiary students. Instead they now have access to smart phones, tablets, laptops, and computers (Dickfos, Cameron, \& Hodgson, 2014). The widespread access to the Internet opens up new learning horizons and enables students to have numerous online resources and websites on their fingertips. Taking in consideration the different pedagogical approaches, staff members have no hesitation in ascertaining that ICT should be an integral subject in all university qualifications (see Figure 1).

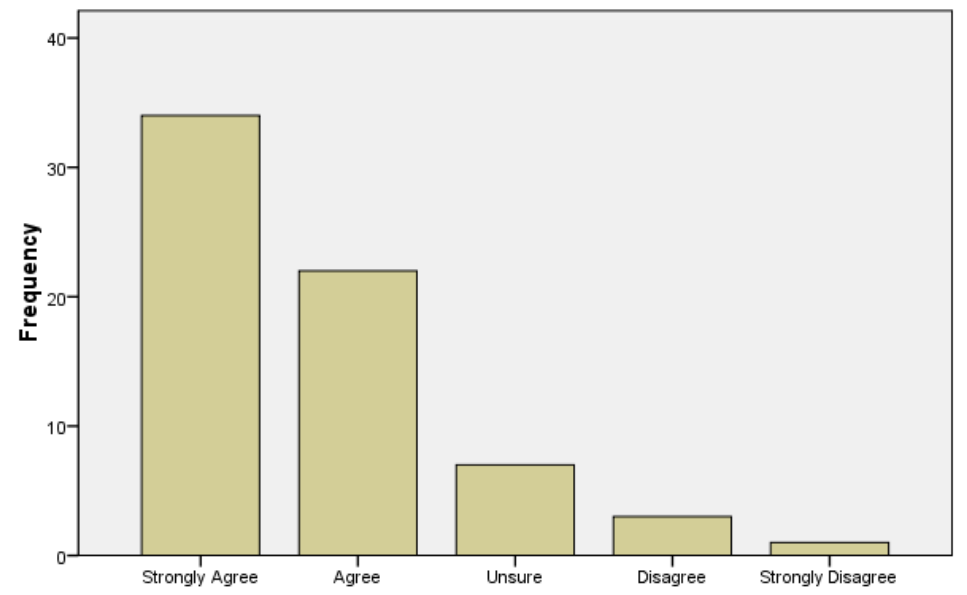

Figure 1. ICT should be an integral aspect of all university qualifications

Findings reveal that majority (84\%) of the staff member either strongly agree $(51 \%)$ or agree $(33 \%)$ that ICT should be an important aspect in all programs offered at tertiary institutions. This metamorphosis would enable students to acquire basic computer illiteracies to successfully compete and survive in a digital milieu. There was certain amount of uncertainties (10\%) and disagreements (5\%) as some of the staff believed that students enrolled in language and literature and in arts do not require ICT as it is not of any value to them. However, considering the digital age, it is widely anticipated that we cannot live and work in this world without ICT. Accordingly, there are numerous advantages of digital networking as it allows countless transactions to occur in painless and expeditious ways. Likewise, integrating technology in education enhances the effectiveness and presents a new a dimension to learning that was not formerly available to many. Considering its influential nature, it can be assumed that ICT integrated education is the way forward for the $21^{\text {st }}$ century learners and educators.

\section{Staff Readiness}

Given the relentless advent of ICT in education arena, its use in enhancing classroom based instruction has been widely discussed and adopted in many HE institutions globally. American Psychological Association, as one of its recommendations has encouraged lecturers' to reckon implementing ICT integrated learning environment for students (Li, Yamaguchi, \& Takada, 2018). In this regard, Vrasidas (2015) is quite skeptical as institutions may have necessary ICT facilities, but there may be other shortfalls such as lack of time for lesson preparation and unsupportive curriculum design. He reiterates that just having the resources does not imply that ICT can be easily implemented but there needs to be the presence of other supportive factors and one such factor is teacher 
readiness (Vrasidas, 2015). That is why Yunus (2007) is assertive that before ICT can be effectively integrated lecturers' should be provided adequate training and support in ICT and pedagogy. There is no doubt why staff readiness and motivation needs to be considered as important factors for the successful assimilation of technology in HE institutions.

While majority of the staff members seem to be integrating ICT in their lessons especially during lectures and tutorials, majority (92\%) of them still believe that confidence is a factor that can be further enhanced (see Table 6). This lack of confidence could be due to the administration of the different tools and learning platforms.

Table 6. Staff members need confidence to integrate ICT in teaching

\begin{tabular}{lll}
\hline & Frequency & Percent \\
\hline Strongly Agree & 28 & 41.8 \\
Agree & 34 & 50.7 \\
Unsure & 4 & 6.0 \\
Disagree & 1 & 1.5 \\
Total & 67 & 100.0 \\
\hline
\end{tabular}

A few (8\%) of the staff members were a bit unsure and disagreed as they may be the ones not integrating ICT in their lessons.

On similar note, Huang \& Liaw (2005) are assertive that staff members' attitude and their willingness to implement ICT makes a big difference in the lives of their students. Similar sentiments are shared by Yuen and Ma (2002) who strongly recommend the need to empower teaching staff and build their confidence so that they are able to implement ICT integrated teaching. Previous studies reveal that teaching staff have difference of opinion in regards to implementing technology in teaching (Agyei \& Voogt, 2011; Albugarni \& Ahmed, 2015; Lim \& Khine, 2006). Likewise, Lim and Khine (2006) have gone a step further and reiterated that one of the main determiners of either success or failure of any ICT initiative in education is the teacher. Similar views are being shared by Martin (2000) who strongly advocates the important role played by teachers' as he labels them as gatekeepers of the classroom and similar understanding is also shared by Yunus (2007). On similar note, Coll, Mauri, \& Onrubia, (2009) agree that despite there have been certain levels of ICT integration and compliance in education sectors globally, the teaching style and strategies have remained the same.

Having similar concerns, Mirzajani, Mahmud, Ayub, \& Wong (2016) under took a study to ascertain features that influence lecturers' inspiration to use ICT in the classroom. Their findings further reveal that lecturers' in the study had not received adequate training in ICT education as such they lacked confidence in using technology based teaching effectively. Moreover, lack of access to ICT facilities and back up technical support structure were some of the reasons why even interested staff members were unable to implement technology integrated teaching (Hassan Mirzajani et al., 2016). Findings further reveal that structured professional development and guidance and assistance from school administrators are viewed as main factors that promotes the integration of technology in education(Hassan Mirzajani et al., 2016). As such, it also must be established that lecturers' need to have basic ICT knowledge in order to successfully implement ICT tools in classroom instruction activities. Likewise, according to Siplia (2011) although majority of the schools in Finland have well established ICT infrastructure and support services, their education board still conducted series of trainings and short courses to upgrade staff members' technological expertise.

Literature further entails that despite initiatives like in-service training, there are still many lecturers' who lack basic ICT knowledge and skills to implement ICT gadgets for teaching purposes (Sipilä, 2011). In similar vein, the findings from the current research are in congruent with Siplia (2011) as it ascertains that majority (90\%) of the staff members anticipate that staff professional development is needed as it improves the integration of ICT in pedagogy and practice.

Table 7. Staff professional development in ICT education

\begin{tabular}{lll}
\hline & Frequency & Percent \\
\hline Strongly Agree & 36 & 53.7 \\
Agree & 25 & 37.3 \\
Unsure & 3 & 4.5 \\
Disagree & 2 & 3.0 \\
Strongly Disagree & 1 & 1.5 \\
Total & 67 & 100.0 \\
\hline
\end{tabular}


There is no doubt that lecturers' should be computer literate even if they are digital natives as there are many more things to learn in ICT to be able to implement technological tools effectively in classrooms. Previous research reveal that the connotation of lecturers' application of technology in education has developed and is no longer limited to basic PowerPoint presentations (Li et al., 2018). However, it must be established that neither technology nor technological tools directly influence learning environment, it is the effective integration of it that makes the difference in learning (Earle, 2002). Literature further mentions that staff members' willingness and understanding of the importance of ICT are much needed components that contribute towards effective learning environment (Kamaruddin, Abdullah, Idris, \& Nawi, 2017). As such it can be established that staff readiness is one of the most important factors that contributes towards the effective implementation of ICT integrated learning and teaching environment.

\section{Quality Internet Service}

The world is moving swiftly towards ubiquitous connectivity and this phenomenon has changed how we think and live in the $21^{\text {st }}$ century. The internet has revolutionized the world as it has broken all barriers of distance, location and time (Tran Dinh Tan, Polyakova, \& Shipilova, 2015). Likewise, internet has become an important instructional tool in higher education institutions globally. According to Hung, Huang, and Hwang (2014) a simple search online can result in getting many educational websites with abundance of learning resources in a short span of time. In the current study majority $(82 \%)$ of the staff members either strongly agreed (31\%) or agreed (51\%) that high quality internet service is a much needed commodity for the effective integration of ICT in pedagogy (see Figure 2).

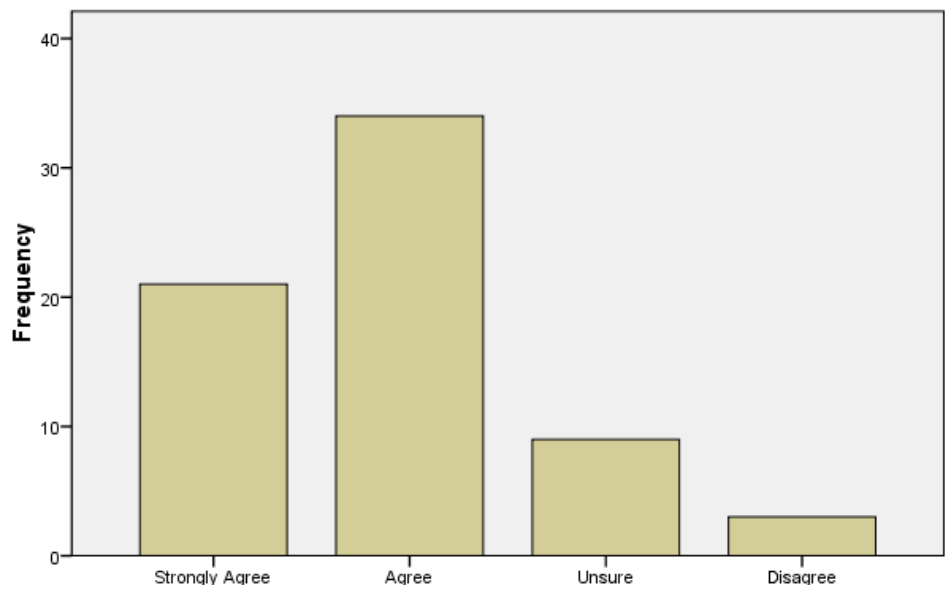

Figure 2. High quality internet service facilitates integration of ICT

Some of the staff members were a bit unsure as much of the work can be downloaded prior to lessons for reuse and repeat lectures. There is no doubt that the use of internet as a teaching tool has spread at a rapid rate and many tertiary institutions have been found to be using learning platforms like Moodle to supplement student learning.

Ruzgar (2005) agrees with (Becker, 2000) that it is common in tertiary institutions to provide online support and guidance to enrich traditional teaching. A study undertaken by Laird and Kuh (2005) confirm that our students are quite well acquainted with technology and many of them use internet to do research and for personal reasons. Whilst considering the many benefits of integrating ICT in the lessons, one needs to bear in mind a number of perquisites in form of resources and facilities. It also needs to be established that lack of backup service to implement ICT in classrooms implies lack of positive outcome (Newhouse, 2002).

While there is ample literature that supports the effective integration of ICT in lesson delivery, it must be established that it is not all plain sailing. Majority (94\%) of the staff members are of the firm belief that in order to integrate ICT effectively in lessons, they need to have preparations and planning. According to Shaibou, Moluayonge, and Park (2017) active integration of ICT requires a constant supply of electricity, unfettered access to internet, ample ICT resources and appropriate infrastructural support. Findings further reveal that a few (4\%) of the members were either unsure or disagreed may be due to their seldom use of ICT in the classes or maybe they are digital immigrants. Digital immigrants do have a fear of technology and many seem comfortable using the traditional methods of teaching. Indeed, internet has become the great engine of educational and socio-economic development and in due process, it has changed the lives of the net generation the world over. Ultimately, 
integrating ICT in classroom instruction is one way of making learning meaningful and interesting for our young minds and successfully contribute towards creating knowledge based scholars.

\section{Students Receptiveness of ICT}

Students of today are known by many names, like digital natives (Prensky, 2001), millennial (Howe \& Strauss, 2000), net generation (Tapscott, 1998) and digital generation (Ali, 2018). Their entry in the world was at a time when technological expansion was ubiquitous and widely adopted throughout the world. A previous research undertaken by the author has revealed that students tend to have a strong bonding with ICT (Ali, 2018). Today's children are exposed to technological gadgets such as mobile phones and tablets from very tender ages the world over (Shava, Chinyamurindi, \& Somdyala, 2016). An empirical study undertaken by Jesse (2015) confirms the aforementioned comment as his findings reveal that majority (99.8\%) of the students have access to have mobile phones and they use it for texting, visiting social media and applications apart from talking. Looking at the rate at which technology is integrated in the education system, it can be assumed that students' display a high degree of acceptance and receptiveness towards it (Willms \& Corbett, 2003).

However, it must be established that just having the knowledge about using mobile phones and playing online games does not make one ICT literate. Students need basic computer education in terms of using learning platforms like Moodle. Majority (93\%) of the staff members believe that students need ICT knowledge to effectively use Apps and softwares as new pedagogical tools of learning (see Table 8).

Table 8. Students need basic ICT knowledge

\begin{tabular}{llll}
\hline & & Frequency & Percent \\
\hline Valid & Strongly Agree & 34 & 50.7 \\
& Agree & 31 & 46.3 \\
& Unsure & 2 & 3.0 \\
& Total & 67 & 100.0 \\
\hline
\end{tabular}

Likewise, there are certain paradoxes and delusions associated with net generation that needs to be considered as the belief that they know all about ICT is a fatal misconception. Not covering ICT content in study programs due to such fallacies risks leaving students without much needed competencies for employment (ECDL, 2015). For despite they may be technology canny but they may lack the theoretical knowledge base required for particular occupation. Evidence for in support can be found in the study of O'Sullivan (2018) who strongly advocates that many young people, the so-called digital natives, have shown limitations in their use of technology. There have been numerous studies worldwide and one such study in 2014 signposted a huge disparity between young people's false impression and their real knowledge of computer skills (Sommer, 2014). As such, it needs to be realized that the net generation may be good at playing computer games but their actual ICT knowledge may not be adequate for employability purposes. Indeed, this botheration may have directed Prensky to establish the notion of digital wisdom. A term coined to illustrate a digitally wise person who is well versed with digital technologies and is able to make wise choices and sound critical decisions. In essence, young generation need to attain digital wisdom and higher order skills in order to implement digital technologies ethically and efficiently in their lives (Prensky, 2012).

\section{Making ICT Integration a Reality}

ICT has become an integral part of everyday life and has transformed the learning environment to the extent that ICT literacy has become a functional requirement for nearly all qualifications. The integration of technology in education has not only changed how students learn but has also changed the teaching pedagogies by promoting collaborative activities (Haddad, 2003). Hence, ICT immersed lessons provide a motivating and encouraging learning environment for our students and also it leads to self-directed learning. Majority (94\%) of the staff members are very supportive of this idea and they believe it is a common feature of many tertiary institutions. There is no doubt that the teaching staff in form of professors, lecturers and teaching assistants are the key players in the effective implementation of ICT integrated learning (Aydin, 2012; Buabeng-Andoh, 2015; Sipilä, 2011). As such, it is pivotal that they have the right attitude and perceptions about ICT so that they can integrate technology effectively in teaching. Likewise, students' perceptions and aspirations also need to be considered as it directly affects their learning space and style (Buabeng-Andoh \& Totimeh, 2012; Fu, 2013; Jung, 2005; Hassan Mirzajani, Mahmud, Fauzi Mohd Ayub, \& Wong, 2016).

There is no doubt that massive technological advances in the world demand a paradigm shift in way we approach our educational goals and aspirations. Many universities and educational institutions have adopted ICT tools 
such as laptop, projectors, tablets, smart phones, ipads and interactive white boards to mention a few. This is apart from many educational softwares and learning applications readily available on the internet. Likewise, the current findings reveal that staff members have found that students have a special bonding with ICT. They further believe that todays' students are quite attached to mobile technology and look forward to technology integrated learning. Table 9 reflects this attachment of students as perceived by staff members.

Table 9. ICT tools as a facilitator of 21 st century pedagogy

\begin{tabular}{lll}
\hline & Frequency & Percent \\
\hline Strongly Agree & 37 & 55.2 \\
Agree & 23 & 34.3 \\
Unsure & 4 & 6.0 \\
Disagree & 2 & 3.0 \\
Strongly Disagree & 1 & 1.5 \\
Total & 67 & 100.0 \\
\hline
\end{tabular}

Majority (90\%) of the staff members see ICT tools as facilitators of $21^{\text {st }}$ century pedagogy. These staff members integrate ICT in their lessons and see it as a meaningful pedagogy. However, there were a few uncertainties (6\%) and disagreements (5\%) maybe due to lack of ICT knowledge and skills. Views expressed by Banitt, Theis, and Leeuwe (2013) validates the findings as according to them lecturers who are digital immigrants (see Prensky, 2001), do front difficulties in using ICT tools confidently during their teaching. This is because they did not grow up with ubiquitous technological expansion and as such they require professional development to effectively implement ICT based classroom instructions.

None the less, students' receptiveness of ICT is well acknowledged by all. On similar note, Buabeng-Andoh and Yidana (2014) are in acquiesce with the views of Earle (2002) that students look forward to ICT integrated learning and as it enables them to use internet and catch up with lessons from the comforts of their homes. This impetus in students calls for lecturers and administrators to have adequate ICT infrastructure and student support services to make learning meaningful and enjoyable for all. In essence, it can be concluded that lecturers and teaching staff in general are key stakeholders in the successful implementation of ICT integrated learning and reciprocally they need to be valued and assisted accordingly.

\section{Limitations}

Naturally, studies do have certain limitations and in this case it was the single method used to collect data. The results in this study could not be verified by other means such as observations and other independent measures as only a survey was used in the study. Moreover, the sample only included staff members from one tertiary institution as such the findings may not be generalizable to the entire population of tertiary educators. Consequently, these results should be viewed as a snapshot of tertiary educators' perception of the influence of evolving technology in conceptualizing pedagogy and practice in higher education. Thus, the exploratory findings present a solid platform for debate and discussion and scope for further in-depth research on the subject matter.

\section{Implications and Conclusion}

The perceptions of staff members greatly influence the effective implementation of ICT integrated pedagogy and practice in higher education. Findings reveal that apart from staff members, this study has certain significant implications for institutions, educators and students alike. Foremost, in order to implement ICT effectively staff members need to have the basic ICT tools and access to applications and learning platforms. Staff members also need to have the capacity to use the ICT tools effectively to offer lessons in such a mode. Subsequently, this study acknowledges the view that apart from staff, student readiness needs to be acknowledged and supported accordingly. There should not be room for myths and false impressions about students' capabilities and appropriate assessment and guidance should be provided. On similar note, administration has to see the availability of digital tools and have respective support structure in place as almost all ICT tools need electricity to operate and require high quality internet connection. Staff members' perceptions further reveal that students as well as staff need the support and guidance to be more receptive to ICT based pedagogy and practice.

In essence, ICT has become a potent force in transforming the educational landscape the world over. A lot of people now have computers and can access Internet and social media like Facebook on a daily basis. Having being exposed to these types of environment our students would also like to learn differently in a more technology oriented context. Findings reveal that staff members are generally quite optimistic of integrating ICT 
in classroom instruction as they see it as meaningful pedagogical tool that makes learning more engaging and motivational for students. They see the high level of student satisfaction and interest as the learning gains in ICT immersed learning environment.

In similar vein, members' perceptions of ICT integrated environment are diverse and numerous. However, majority of them see ICT integrated pedagogy and practice as a need for the students in the $21^{\text {st }}$ century. There has obviously been a great influence of technology in the online lives of young people. This digitalised revolution can synergise the educational ambitions and interests of the students who have become digital addicts. Findings provide an awakening call for tertiary educators as they need to integrate ICT in pedagogy and practice to suit $21^{\text {st }}$ century learners. In essence, it can be established that education systems need to be abreast with the rapid emergence of new technologies, thus making ICT integrated instruction inevitable at tertiary level not only in Fiji but the world over.

\section{Reference}

Aczel, J. C., Peake, S. R., \& Hardy, P. (2008). Designing capacity-building in e-learning expertise: challenges and strategies. Computers \& Education, 50(2), 499-510. https://doi.org/10.1016/j.compedu.2007.07.005

Agbatogun, A. O. (2013). Interactive digital technologies' use in Southwest Nigerian universities. Educational Technology, Research and Development, 61(2), 333-357. http://dx.doi.org/10.1007/s11423-012-9282-1

Agyei, D. D., \& Voogt, J. (2011). ICT use in the teaching of mathematics: Implications for professional development of pre-service teachers in Ghana. Education and Information Technologies, 16(4), 423-439. http://dx.doi.org/10.1007/s10639-010-9141-9

Albugarni, S., \& Ahmed, V. (2015). Success factors for ICT implementation in Saudi secondary schools: From the perspective of ICT directors, head teachers, teachers and students. International Journal of Education and Development using Information and Communication Technology, 11(1), 36-54.

Ali, W. (2018). Influence of Evolving Technology in Emerging Online Lives of the Digital Native University Students. Asia Pacific Journal of Contemporary Education and Communication Technology, 4(2), 141-155. https://doi.org/10.25275/apjcectv4i2edu15

Allen, I. E., \& Seaman, J. (2013). Changing Course: Ten Years of Tracking Online Education in the United States. Retrieved from https://www.onlinelearningsurvey.com/reports/changingcourse.pdf

Aydin, S. (2012). A review of research on Facebook as an educational environment. Educational Technology, Research and Development, 60(6), 1093-1106. http://dx.doi.org/10.1007/s11423-012-9260-7

Baker, H. K., \& Mukherjee, T. K. (2007). Survey research in finance: views from journal editors. International Journal of Managerial Finance, 3(1), 11-25. http://dx.doi.org/10.1108/17439130710721635

Banitt, J., Theis, S., \& Leeuwe, V. L. (2013). The Effects of Technology Integration on Student Engagement. In fulfillment of final requirements for the MAED degree. St. Catherine University. St. Paul, Minnesota.

Barber, M., \& Mourshed, M. (2007). How the world's best-performing school systems come out on top. London, UK: McKinsey \& Company.

Becker, H. J. (2000). Who's wired and who's not: Children's access to and use of computer technology. The Future of Children, 10(2), 44-75. https://doi.org/10.2307/1602689

Buabeng-Andoh, C. (2015). ICT usage in Ghanaian secondary schools: teachers' perspectives. The International Journal of Information and Learning Technology, 32(5), 300-312. https://doi.org/10.1108/IJILT-09-2015-0022

Buabeng-Andoh, C., \& Totimeh, F. (2012). Teachers' innovative use of computer technologies in classroom: A case of selected Ghanaian schools. International Journal of Education and Development using Information and Communication Technology, 8(3), 22-34.

Buabeng-Andoh, C., \& Yidana, I. (2014). An investigation of secondary school students' attitudes toward pedagogical use of ICT in learning in Ghana. Interactive Technology and Smart Education, 11(4), 302-314. https://doi.org/10.1108/ITSE-10-2013-0024

Cant, M. C., \& Bothma, C. H. (2010). The learning-technology conundrum: Lecturers' perspectives. Progressio, 32(1), 55-73.

Carr, N. (2017). How smartphones hijack our minds. The Wall Street Journal, 1-2.

Cheta, W. (2014). Acclimatizing to Digital Natives Environment (DNE) in Developing Nations. Journal of 
Research \& Method in Education, 4(1), 21-25. https://doi.org/10.9790/7388-04112125

Chisalita, O. A., \& Cretu, C. (2015, 2015). ICT SUPPORT AND ICT USE IN ROMANIAN SECONDARY EDUCATION, Bucharest.

Coll, C., Mauri, T., \& Onrubia, J. (2009). Towards modeling of the teaching - learning mediated by ICT. Educational Technology, Teacher education in the Internet age, 145-161.

Corrin, L., Bennett, S., \& Lockyer, L. (2011). The life of a 'digital native'. In T. Bastiaens \& M. Ebner (Eds.), ED-MEDIA 2011: World Conference on Educational Multimedia, Hypermedia and Telecommunications (pp. 2942-2951). Chesapeake, VA: AACE.

Dickfos, J., Cameron, C., \& Hodgson, C. (2014). Blended learning: making an impact on assessment and self-reflection in accounting education. Education Training, 56(2/3), 190-207. https://doi.org/10.1108/ET-09-2012-0087

Drossel, K., Eickelmann, B., \& Gerick, J. (2017). Predictors of teachers' use of ICT in school - the relevance of school characteristics, teachers' attitudes and teacher collaboration. Education and Information Technologies, 22(2), 551-573. http://dx.doi.org/10.1007/s10639-016-9476-y

Earle, R. S. (2002). The Integration of Instructional Technology into Public Education: Promises and Challenges. Educational Technology \& Society, 42(1), 5-13.

ECDL. (2015). The Fallacy of the 'Digital Native': Why Young People Need to Develop their Digital Skills. Retrieved from http://ecdl.org/media/TheFallacyofthe\%27DigitalNative\%27PositionPaper1.pdf

Elisha, O. M., Odini, C., \& Ojiambo, J. B. (2013). Use of information communication technologies in education and training of undergraduate library and information science students in two selected Kenyan universities. Library Review, 62(8/9), 585-601. http://dx.doi.org/10.1108/LR-08-2012-0083

Fu, J. S. (2013). ICT in Education: A Critical Literature Review and Its Implications. International Journal of Education and Development using Information and Communication Technology, 9(1), 112-125.

GarcÃa, A. d. 1. P. a. (2014). SOCIAL CAPITAL, CULTURE AND THEORIES OF DEVELOPMENT*. AntÃpoda: Revista de AntropologÃa y Arqueolog Ãa, 18, 217-239. https://doi.org/10.7440/antipoda18.2014.10

Gilakjani, A. P., Leong, L. M., \& Ismail, H. N. (2013). Teachers' use of technology and constructivism. International Journal of Modern Education and Computer Science, 4(5), 49-63. https://doi.org/10.5815/ijmecs.2013.04.07

Gupta, M., \& Dharamveer. (2017). Prospective Teacher's Attitude towards the Use of ICT: A Comparative Study between C.C.S. University, Meerut \& Kurukshetra University, Kurukshetra. Educational Quest, 8(1), 81-88. http://dx.doi.org/10.5958/2230-7311.2017.00014.9

Haddad, W. D. (2003). Is instructional technology a must for learning?. Retrieved from http://www.techknowlogia.org/TKL_active_pages2/CurrentArticles/main.asp?IssueNumber=19\&FileType= HTML\&ArticleID $=455$

Hew, K. F., \& Brush, T. (2007). Integrating technology into K-12 teaching and learning: current knowledge gaps and recommendations for future Research. Educational Technology Research and Development, 55(3), 223-252. https://doi.org/10.1007/s11423-006-9022-5

Howe, N., \& Strauss, W. (2000). Millenials Rising: The Next Great Generation. New York: Vintage Books.

Huang, H. M., \& Liaw, S. S. (2005). Exploring user's attitudes and intentions toward the web as a survey tool. Computers in Human Behavior, 21(5), 729-743. https://doi.org/10.1016/j.chb.2004.02.020

Hung, C.-M., Huang, I., \& Hwang, G.-J. (2014). Effects of digital game-based learning on studentsâ€тм self-efficacy, motivation, anxiety, and achievements in learning mathematics. Journal of Computers in Education, 1(2), 151-166. https://doi.org/10.1007/s40692-014-0008-8

Jaffer, S., Ngambi, D., \& Czerniewicz, L. (2007). The role of ICTs in higher education in South Africa: one strategy for addressing teaching and learning challenges. International Journal of Education and Development using ICT, 3(4), 131-142.

Jesse, G. R. (2015). Smartphone and App Usage Among College Students: Using Smartphones Effectively for Social and Educational Needs. Retrieved from http://proc.iscap.info/2015/pdf/3424.pdf

Jung, I. (2005). ICT-Pedagogy Integration in Teacher Training: Application Cases Worldwide. Journal of 
Educational Technology \& Society, 8(2).

Kamaruddin, K., Abdullah, C. A. C., Idris, M. N., \& Nawi, M. N. M. (2017). Teachers'Level of Ict Integration In Teaching and Learning: A Survey In Malaysian Private Preschool. Paper presented at the AIP Conference Proceedings. https://doi.org/10.1063/1.5005408

Kay, R. (2006). Evaluating strategies used to incorporate technology into preservice education: Education: A review of the literature. Journal of Research on Technology in Education, 38(4), 383-408. https://doi.org/10.1080/15391523.2006.10782466

Laird, T. F. N., \& Kuh, G. D. (2005). Student Experiences with Information Technology and their Relationship to Other Aspects of Student Engagement. Research in Higher Education, 46(2), 211-233. https://doi.org/10.1007/s11162-004-1600-y

Li, S., Yamaguchi, S., \& Takada, J.-I. (2018). Understanding factors affecting primary school teachers' use of ICT for student-centered education in Mongolia. International Journal of Education and Development using Information and Communication Technology, 14(1), 103-117.

Lim, C. P., \& Khine, M. (2006). Managing teachers' barriers to ICT integration in Singapore schools. Journal of Technology and Teacher Education, 14(1), 97-125.

Martin, W. B. (2000). Learning from the Colwell School: An ethnograpic case study of an educational technology culture. Conwell University. Unpublshed doctoral thesis.

Mirzajani, H., Mahmud, R., Ayub, A. F. M., \& Wong, S. L. (2016). Teachers' acceptance of ICT and its integration in the classroom. Quality Assurance in Education, 24(1), 26-40. https://doi.org/10.1108/QAE-06-2014-0025

Moodle org. (2017). Moodle. Retrieved from https://moodle.org

Morrison, K. (2015). Report: Digital Natives Do Everything From Mobile Devices. Retrieved from http://www.adweek.com/digital/report-digital-natives-do-everything-from-mobile-devices

Newhouse, C. P. (2002). A framework to articulate the impact of ICT on learning in schools. Retrieved from http://www.principals.in/uploads/pdf/ICT/ICT.pdf

O’Sullivan, D. (2018). Schools' role in addressing the Digital Native Fallacy Retrieved from http://www.bcs.org/content/ConWebDoc/55719

Prensky, M. (2001). Digital Natives, Digital Immigrants. On the Horizon, 9(5), 1-6. https://doi.org/10.1108/10748120110424816

Prensky, M. (2012). From Digital Natives to Digital Wisdom: Hopeful Essays for 21st Century Learning. Thousand Oaks: Corwin. https://doi.org/10.4135/9781483387765

Rosen, L. (2010). Rewired. New York: Palgrave MacMillan.

Ruzgar, N. S. (2005). A Research on the Purpose of Internet usage and learning via internet. The Turkish Online Journal of Educational Technology, 4(4).

Sadegül Akbaba, A., Kalayci, E., \& Avci, Ü. (2011). Integrating ICT at the Faculty Level: A Case Study. TOJET : The Turkish Online Journal of Educational Technology, 10(4).

Shah, M., \& Stanford, S.-A. Quality and Regulation of Australian Tertiary Education: Searching for a Sustainable Quality Assurance Framework. The ACPET Journal for Private Higher Education, 2(1), 25-34.

Shaibou, a. H., Moluayonge, G. E., \& Park, I. (2017). Teachers' Use of Information and Communications Technology in Education: Cameroon Secondary Schools Perspectives. TOJET: The Turkish Online Journal of Educational Technology, 16(3).

Shava, H., Chinyamurindi, W., \& Somdyala, A. (2016). An investigation into the usage of mobile phones among technical and vocational educational and training students in South Africa. South African Journal of Information Management, 18(1), 1-8. http://dx.doi.org/10.4102/sajim.v18i1.716

Sipilä, K. (2011). No pain, no gain? Teachers implementing ICT in instruction. Interactive Technology and Smart Education, 8(1), 39-51. http://dx.doi.org/10.1108/17415651111125504

Sommer, H. (2014). Digital competence study. Intermediate results. Retrieved from https://www.youtube.com/watch?v=BtAFgBiTb5g

Tapscott, D. (1998). Growing Up Digital: The Rise of the Net Generation. New York: McGraw-Hill. 
Thurlings, M., Evers, A. T., \& Vermeulen, M. (2015). Toward a model of explaining teachers' innovative behavior - A literature review. Review of Educational Research, 85(3). https://doi.org/10.3102/0034654314557949

Tran, D. T. X., Polyakova, N. S., \& Shipilova, S. S. (2015, 2016). Social Internet-networks in the life of Vietnamese students. Paper presented at the SHS Web of Conferences, Les Ulis.

Twidle, J., Sorensen, P., Childs, A., Godwin, J., \& Dussart, M. (2006). Issues, challenges and needs of student science teachers in using the Internet as a tool for teaching. Technology, Pedagogy and Education, 15(2), 207-221. https://doi.org/10.1080/14759390600769680

UNESCO. (2002). ICTs in teacher education: a planning guide. Paris: Division of Higher.

Vrasidas, C. (2015). The rhetoric of reform and teachers' use of ICT. British Journal of Educational Technology, 46(2), 370-380. https://doi.org/10.1111/bjet.12149

Vrasidas, C., \& McIsaac, M. (2001). Integrating technology in teaching and teacher education: Implications for policy and curriculum reform. Educational Media International, 38(2/3), 127-132. https://doi.org/10.1080/09523980110041944

Willms, J. D., \& Corbett, B. A. (2003, Summer). Tech and teens: access and use [2000 data]. Canadian Social Trends, 15-20.

Yin, R. K. (2011). Qualitative Research from Start to Finish. New York, NY 10012: The Guilford Press.

Yuen, A., \& Ma, W. (2002). Gender differences in teacher computer acceptance. Journal of Technology and Teacher Education, 10(3), 365-382.

Yunus, M. M. (2007). Malaysian ESL teachers' use of ICT in their classrooms: expectations and realities. ReCALL : the Journal of EUROCALL, 19(1), 79-95. https://doi.org/10.1017/S0958344007000614

Zaffar Ahmed, S., \& Shakeel, A. K. (2011). Role of ICT in shaping the future of Pakistani Higher Education System. TOJET: The Turkish Online Journal of Educational Technology, 10(1).

\section{Copyrights}

Copyright for this article is retained by the author(s), with first publication rights granted to the journal.

This is an open-access article distributed under the terms and conditions of the Creative Commons Attribution license (http://creativecommons.org/licenses/by/4.0/). 